\title{
Calcific Myonecrosis of the Leg: A Rare Entity
}

\author{
Andrea Angelini ${ }^{1}$, Andreas F. Mavrogenis ${ }^{2}$, Elisa Pagliarini ${ }^{1}$, Giulia Trovarelli ${ }^{1}$, \\ Giuseppe Nicolò Fanelli ${ }^{3}$ (D), Rocco Cappellesso ${ }^{3}\left(\mathbb{D}\right.$ and Pietro Ruggieri ${ }^{1}$ * \\ 1 Department of Orthopaedics and Orthopaedic Oncology, University of Padova, 35128 Padova, Italy \\ 2 First Department of Orthopaedics, National and Kapodistrian University of Athens, School of Medicine, \\ 11527 Athens, Greece \\ 3 Department of Medicine, Surgical Pathology \& Cytopathology Unit, University of Padova, \\ 35128 Padova, Italy \\ * Correspondence: pietro.ruggieri@unipd.it; Tel.: +39-0498213311
}

Received: 25 June 2019; Accepted: 23 August 2019; Published: 28 August 2019

\begin{abstract}
Calcific myonecrosis is a rare disease that has been shown to be a late sequela of trauma. This article presents a 68-year-old man with calcific myonecrosis of the leg 40 years after a tibial fracture complicated with peroneal nerve palsy. The soft tissue mass increased in size after another injury to the leg that occurred two years before his presentation. Physical examination at presentation showed a palpable extra-osseous mass at the anterior aspect of the left leg; the mass was not adherent to adjacent soft-tissues and bone, and it was painless but tender to palpation. Radiographs of the left leg showed extensive calcification at the soft-tissue of the anterior and posterior leg. An ultrasonography-guided trocar biopsy was done; histological findings were indicative of calcific myonecrosis. Given the benign entity of the lesion and known high rate of complications, he was recommended for no further treatment except for clinical and imaging observation. Located at the site of the biopsy, he experienced infection with drainage that eventually healed after six months with antibiotics and wound dressing changes. During the last follow-up examination, two years after diagnosis, the patient was asymptomatic without progression of the mass.
\end{abstract}

Keywords: calcific; myonecrosis; trauma

\section{Introduction}

Calcific myonecrosis is a rare disease that has been shown to be a late sequela of trauma [1,2]. The time of the onset of symptoms is significantly different from the initial injury and progresses slowly over a period of several years, making an accurate diagnosis difficult. First described more than 40 years ago by Gallie and Thomson [1], it is characterized by the replacement of muscle in one or more compartments with a fusiform mass or masses showing peripheral calcification and central liquefaction. It has been reported to develop primarily in the leg and has been attributed to trauma, such as a fracture accompanying ischemic symptoms and/or peripheral nerve injury [1-27]. Although not well understood, it is postulated that these lesions most likely result from post-traumatic ischemia and cystic degeneration of the muscle [19]. The plaque-like amorphous calcification pattern seen on radiographs is characteristic but not pathognomonic; the calcifications are usually linear in orientation and sheet-like, and present within the entire muscle or compartment, with mixed areas of radiolucency [19]. Smooth bony erosions may be present with minimal periosteal reaction. Occasionally, the erosions may be extensive and worrisome for a soft-tissue tumor; importantly, differential diagnosis should include a sarcoma due to its large size, growth potential and imaging characteristics $[4-7,19]$.

To enhance the literature, this article presents a 68-year-old man with calcific myonecrosis of the leg 40 years after a tibial fracture. The soft tissue mass increased in size after another injury to the leg that occurred two years before his presentation. The diagnostic approach, differential diagnosis 
and treatment are discussed. Written informed consent for publishing this study was obtained from the patient.

\section{Case Report}

A 68-year-old man presented with a progressive painless swelling of his left leg. Past medical history revealed an ipsilateral proximal tibia and fibula fracture 40 years before; the tibial fracture was treated then with an open reduction and internal fixation with a plate and screws. Since then, he experienced a postoperative deficit of the left common peroneal nerve. Two years before, after a minor injury (a muscle strain) to the same leg, he noticed a palpable, painless mass that had increased in size substantially over the last five months.

Physical examination at presentation showed a palpable extra-osseous mass at the anterior aspect of the left leg; the mass was not adherent to adjacent soft-tissues and bone, and it was tender but painless to palpation. The skin was dry and not erythematous. Dorsiflexion of the left foot was weak secondary to the known left common peroneal nerve deficit. Radiographs of the left leg showed extensive calcification at the soft-tissue of the anterior and posterior leg (Figure 1).

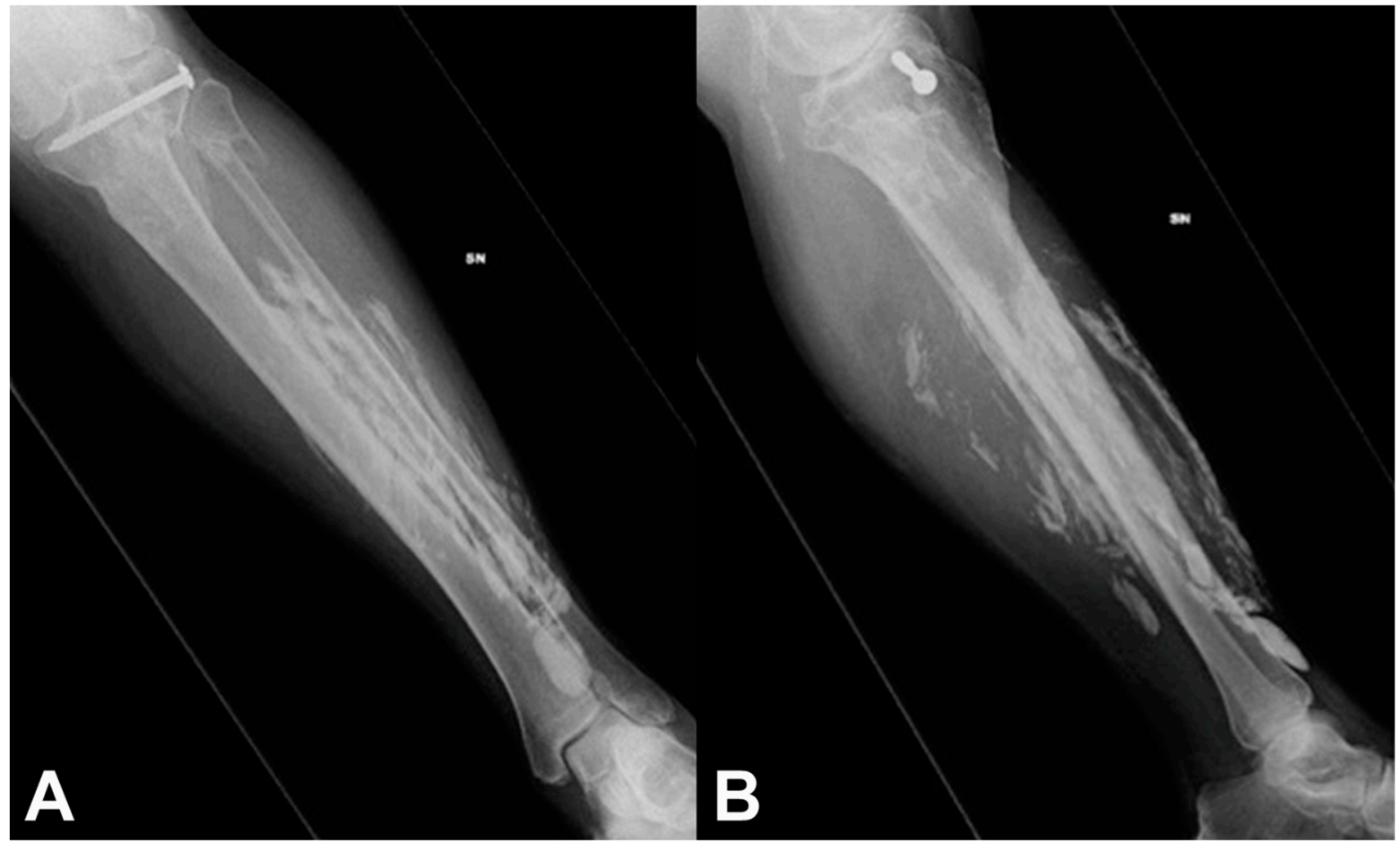

Figure 1. (A) Anteroposterior and (B) lateral radiographs of the left leg of a 68-year-old man with biopsy diagnosed calcific myonecrosis of the leg show extensive calcifications at the soft-tissue of the anterior and posterior leg.

Computed tomography (CT) scan of the left leg showed a calcified fusiform soft-tissue mass with peripheral plaque-like calcification linearly oriented through the muscles of the anterior and posterior leg and extending through the interosseous membrane (Figure 2). 


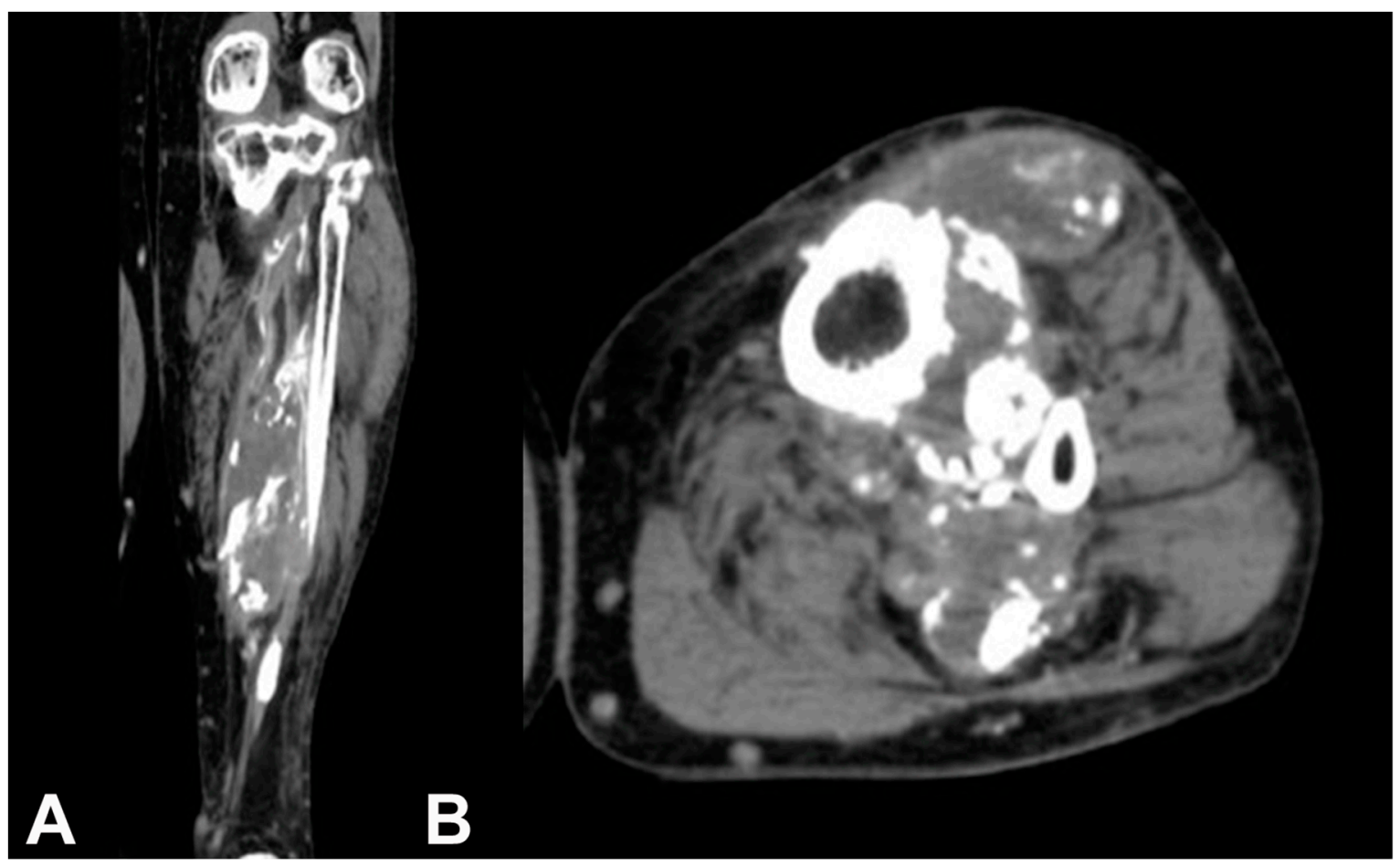

Figure 2. (A) Coronal and (B) axial CT scan of the leg show a calcified fusiform soft-tissue mass with peripheral plaque-like calcification linearly oriented through the muscles of the anterior and posterior leg compartment and interosseous membrane and marked erosion of the fibular cortex. The scalloping of the tibia suggests a slow growing process; central low signal density, and peripheral high density suggests fluid and peripheral calcification.

Laboratory studies were within normal values. To exclude malignancy, an ultrasonography-guided trocar biopsy was done. Histological sections of the biopsy specimens showed multiple fragments of pultaceous s and partially calcified tissue, presence of sclero-hyaline and necrotic tissue with calcifications without any vital cells; histological findings were indicative of the diagnosis of calcific myonecrosis (Figure 3). 


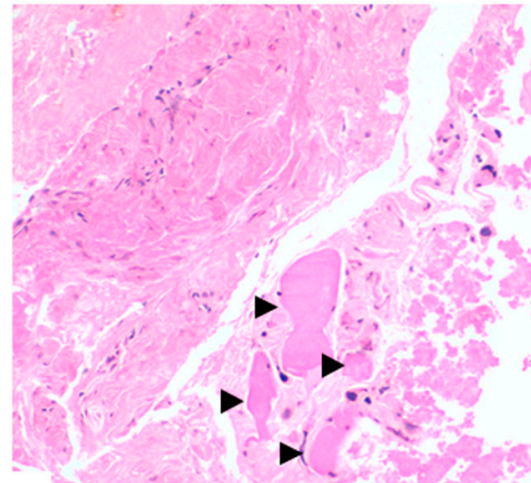

A
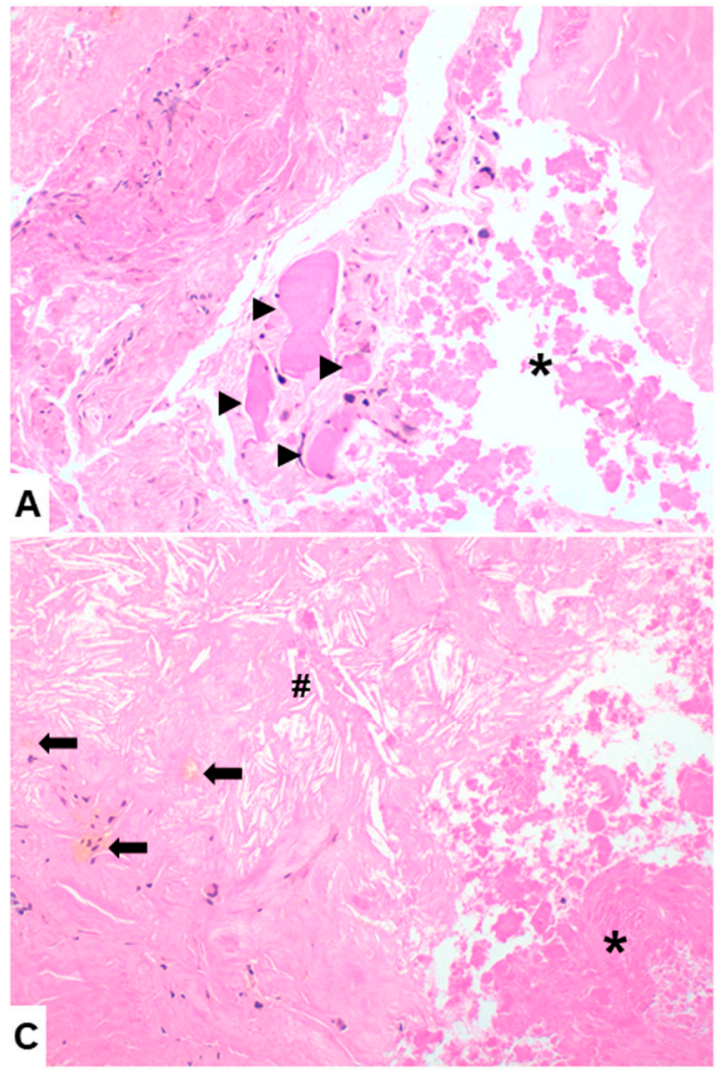

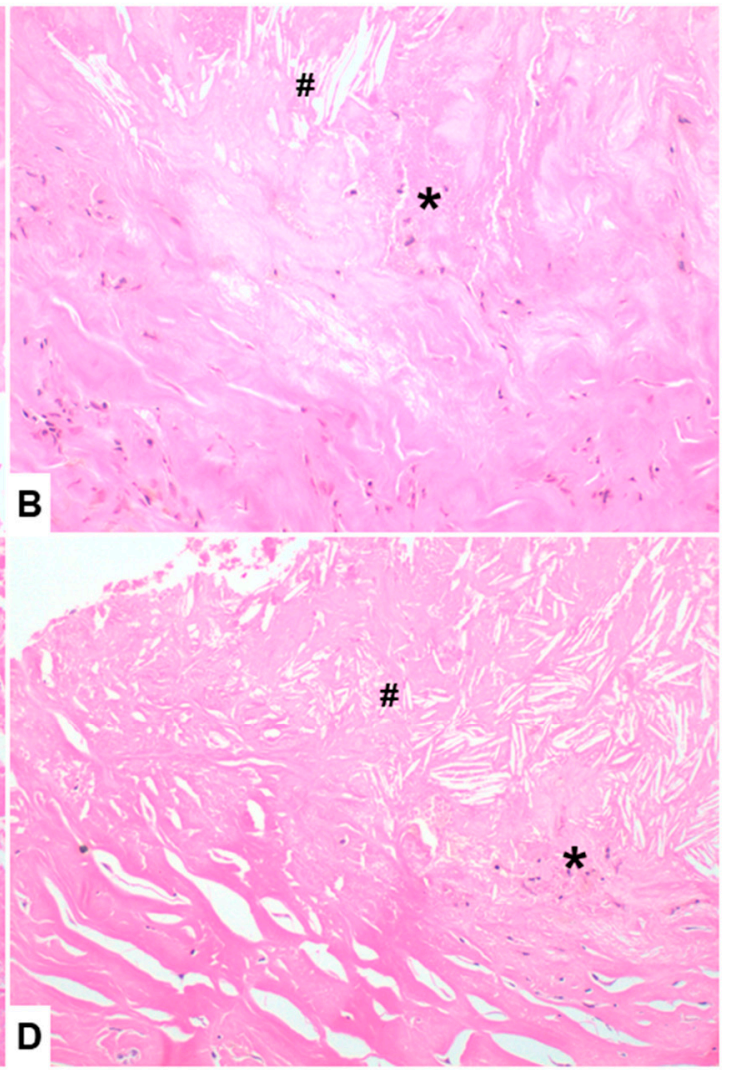

D

Figure 3. (A) Calcific myonecrosis is histologically characterized by degenerating myofibers that exhibit cell swelling, hyper-eosinophilia, loss of cross striation and fragmentation (arrowhead) with pyknotic nuclei. (B-D) Long standing degenerated regions variably can be accompanied by additional myopathic changes, such as extensive necrosis (asterisk) with prominent ghost skeletal muscle fibers, atrophy, sclero-hyalinized foci (top right $(\mathbf{A}, \mathbf{B})$, bottom left $(\mathbf{C}, \mathbf{D})$ ) and inflammatory cells infiltration. Along the areas of more recent haemorrhage, hemosiderin deposits are present (arrow). Cholesterol crystals (diesis) with extensive dystrophic calcification are other distinguishing features.

The patient was informed of the benign entity of the lesion. Given the known high rate of complications, he was recommended for no further treatment except for clinical and imaging observation. Located at the site of the biopsy, he experienced infection with drainage that eventually healed after six months with antibiotics and wound dressing changes. During the last follow-up examination, two years after diagnosis, the patient experiences no noticeable increase in the size of the mass, and diminished pain. Repeat radiographs of the leg were similar to those at presentation. He was advised to continue full activity and to monitor his leg for new symptoms or mass enlargement.

\section{Discussion}

Calcific myonecrosis is rarely reported in literature [1-27]; our literature search came out with 40 cases reported from the original description of the entity (Table 1). Age range varied significantly (range, 17-87 years); patients in their sixth decade of life were affected most frequently. There was a slight male predominance ( 33 male and 7 female patients), as in the present case. The most common area of calcific myonecrosis was the anterior compartment of the leg followed by the lateral and deep posterior compartments; a total of 37 cases were reported in the leg [1,2,4-6,8-21,23-27], two cases in the forearm [3,22], and one case in the foot [7]. 
Table 1. Summary of the published reports on calcific myonecrosis.

\begin{tabular}{|c|c|c|c|c|c|c|c|c|c|}
\hline Study & $\begin{array}{c}\text { Patients/Age, } \\
\text { gender }\end{array}$ & Site & Symptoms (time) & $\begin{array}{l}\text { Previous trauma } \\
\text { (time before) }\end{array}$ & Nerve deficit & Biopsy & Complications & Infection & Treatment \\
\hline Janzen et al. [6] & $77 \mathrm{M}$ & Leg & Mass & Fibular fracture (52 years) & Peroneal & Incisional & Yes & Chronic drainage & n.a. \\
\hline Zohman et al. [10] & $49 \mathrm{M}$ & Leg & Mass & $\begin{array}{l}\text { Ligamentous knee injury } \\
\text { (30 years) }\end{array}$ & Sciatic & Incisional & No & - & Excision \\
\hline Tuncay et al. [25] & $64 \mathrm{M}$ & Leg & Mass ( 3 years) & Shotgun injury (42 years) & Peroneal & Incisional & No & - & Excision \\
\hline Jassal et al. [26] & $66 \mathrm{M}$ & Leg & Mass, pain & Ankle fracture (47 years) & - & Incisional & Yes & $\begin{array}{c}\text { Cellulitis and } \\
\text { drainage }\end{array}$ & Debridement + flap \\
\hline Holobinko et al. [7] & $\begin{array}{l}57 \mathrm{M} \\
67 \mathrm{M} \\
37 \mathrm{M}\end{array}$ & $\begin{array}{l}\text { Leg } \\
\text { Leg } \\
\text { Foot }\end{array}$ & $\begin{array}{l}\text { Mass, pain ( } 2 \text { years }) \\
\text { Mass ( } 3 \text { months) } \\
\text { Plantar drainage }\end{array}$ & $\begin{array}{l}\text { Tibia fracture ( } 40 \text { years) } \\
\text { Tibia fracture (51 years) } \\
\text { Tibia fracture (21 years) }\end{array}$ & $\begin{array}{c}\text { Weakness } \\
- \\
\text { Hyperesthesia }\end{array}$ & $\begin{array}{l}\text { Incisional } \\
\text { Incisional } \\
\text { Incisional }\end{array}$ & $\begin{array}{l}\text { Yes } \\
\text { No } \\
\text { No }\end{array}$ & $\begin{array}{l}\text { Drainage } \\
\text { Drainage } \\
\text { Drainage }\end{array}$ & $\begin{array}{c}\text { Debridement + flap } \\
\text { Debridement } \\
\text { Debridement + flap }\end{array}$ \\
\hline Dhillon et al. [4] & $\begin{array}{c}7 \mathrm{M}, 3 \mathrm{~F} ; \text { mean } \\
\text { age } 68 \text { years } \\
\text { (range, } 40-82 \\
\text { years) }\end{array}$ & Leg & n.a. & $\begin{array}{c}\text { Significant trauma to the } \\
\text { leg (mean, } 46 \text { years; range } \\
28-59 \text { years) }\end{array}$ & n.a. & $\begin{array}{c}\text { Needle } \\
\text { (4 patients) }\end{array}$ & $\begin{array}{l}8 \text { patients } \\
\text { (prolonged } \\
\text { recovery) }\end{array}$ & n.a. & $\begin{array}{l}\text { Debridement } \\
\text { (3 patients) }\end{array}$ \\
\hline Larson et al. [3] & $17 \mathrm{M}$ & Forearm & Mass, pain (4 months) & Crush injury (55 years) & - & Incisional & No & - & Excision \\
\hline Ozbarlas et al. [12] & $77 \mathrm{M}$ & Leg & Mass, pain (2 months) & Blunt trauma (5 years) & - & n.a. & n.a. & - & n.a. \\
\hline Muramatsu et al. [5] & $\begin{array}{l}51 \mathrm{M} \\
52 \mathrm{M} \\
66 \mathrm{M}\end{array}$ & $\begin{array}{l}\text { Leg } \\
\text { Leg } \\
\text { Leg }\end{array}$ & $\begin{array}{l}\text { Mass, pain (3 months) } \\
\text { Growing mass (1 month) } \\
\text { Mass, pain (3 months) }\end{array}$ & $\begin{array}{c}\text { Compartment syndrome. } \\
\text { (35 years) } \\
\text { Tibia fracture ( } 24 \text { years) } \\
\text { Crush injury ( } 40 \text { years) }\end{array}$ & $\begin{array}{c}\text { Peroneal } \\
\text { Tibialis } \\
\quad- \\
\end{array}$ & $\begin{array}{c}\text { Needle } \\
\text { Incisional } \\
- \\
\end{array}$ & $\begin{array}{l}- \\
- \\
-\end{array}$ & $\begin{array}{l}- \\
\text { Osteomyelitis } \\
\text { Yes }\end{array}$ & $\begin{array}{l}\text { Debridement } \\
\text { Aspiration } \\
\text { Aspiration }\end{array}$ \\
\hline Okada et al. [14] & $62 \mathrm{M}$ & Leg & Mass (5 months) & Squeezed trauma (43 years) & Peroneal & Incisional & - & - & Excision \\
\hline $\begin{array}{c}\text { Papanikolaou et al. } \\
\text { [17] }\end{array}$ & $\begin{array}{l}54 \mathrm{M} \\
66 \mathrm{M} \\
84 \mathrm{~F}\end{array}$ & $\begin{array}{l}\text { Leg } \\
\text { Leg } \\
\text { Leg }\end{array}$ & $\begin{array}{l}\text { Mass (10 days) } \\
\text { Mass, pain (1 month) } \\
\text { Infection }\end{array}$ & $\begin{array}{l}\text { Crush injury ( } 7 \text { years) } \\
\text { Artery lesion (52 years) } \\
\text { Crush injury (53 years) }\end{array}$ & $\begin{array}{c}- \\
\text { Peroneal } \\
-\end{array}$ & $\begin{array}{l}- \\
- \\
-\end{array}$ & $\begin{array}{l}- \\
- \\
-\end{array}$ & $\begin{array}{c}\text { Yes } \\
\text { Drainage, fever } \\
\text { Yes, fever }\end{array}$ & $\begin{array}{c}\text { Debridement } \\
\text { Debridement, VACT } \\
\text { Debridement }\end{array}$ \\
\hline Portabella et al. [18] & $\begin{array}{l}55 \mathrm{M} \\
64 \mathrm{M} \\
54 \mathrm{M} \\
77 \mathrm{M}\end{array}$ & $\begin{array}{l}\text { Leg } \\
\text { Leg } \\
\text { Leg } \\
\text { Leg }\end{array}$ & $\begin{array}{l}\text { n.a. } \\
\text { n.a. } \\
\text { n.a. } \\
\text { n.a. }\end{array}$ & $\begin{array}{l}\text { n.a. } \\
\text { n.a. } \\
\text { n.a. } \\
\text { n.a. }\end{array}$ & $\begin{array}{c}\text { Sciatic } \\
\text { Peroneal } \\
\text { Peroneal } \\
\quad- \\
\end{array}$ & $\begin{array}{c}\text { Yes } \\
- \\
- \\
-\end{array}$ & $\begin{array}{l}- \\
\text { Yes } \\
\text { Yes } \\
-\end{array}$ & $\begin{array}{c}- \\
\text { Chronic drainage } \\
\text { Chronic drainage } \\
\text { Yes }\end{array}$ & $\begin{array}{c}- \\
\text { Debridement, VACT } \\
\text { Debridement, VACT } \\
\text { Debridement } \\
\end{array}$ \\
\hline $\begin{array}{c}\text { De Carvalho et al. } \\
\text { [13] }\end{array}$ & $\begin{array}{r}69 \mathrm{~F} \\
73 \mathrm{M} \\
\end{array}$ & $\begin{array}{l}\text { Leg } \\
\text { Leg }\end{array}$ & $\begin{array}{l}\text { Mass ( } 2 \text { months) } \\
\text { Growing mass }\end{array}$ & $\begin{array}{l}\text { Motor vehicle trauma } \\
\text { Tibia fracture ( } 57 \text { years) }\end{array}$ & $\begin{array}{l}- \\
-\end{array}$ & $\begin{array}{l}- \\
-\end{array}$ & - & - & $\begin{array}{l}\text { n.a. } \\
\text { n.a. }\end{array}$ \\
\hline Chun et al. [16] & $53 \mathrm{M}$ & Leg & Growing mass & Snake bite (44 years) & - & - & - & - & n.a. \\
\hline
\end{tabular}


Table 1. Cont

\begin{tabular}{|c|c|c|c|c|c|c|c|c|c|}
\hline Study & $\begin{array}{l}\text { Patients/Age, } \\
\text { gender }\end{array}$ & Site & Symptoms (time) & $\begin{array}{l}\text { Previous trauma } \\
\text { (time before) }\end{array}$ & Nerve deficit & Biopsy & Complications & Infection & Treatment \\
\hline Jalil et al. [20] & $43 \mathrm{M}$ & Leg & Mass, pain (1 month) & Tibia fracture (20 years) & - & - & - & - & Debridement \\
\hline Karkhanis et al. [21] & $60 \mathrm{M}$ & Leg & Growing mass (4 months) & - & - & - & - & - & - \\
\hline Rynders et al. [22] & $66 \mathrm{M}$ & Forearm & Growing mass (2 months) & Elbow fracture (57 years) & - & - & - & n.a. & n.a. \\
\hline $\begin{array}{l}\text { Yuenyongviwat et al. } \\
\text { [23] }\end{array}$ & $66 \mathrm{~F}$ & Leg & Mass (10 years) & Snake bite (14 years) & Peroneal & Yes & Yes & Yes & Excision \\
\hline Ukon et al. [24] & $\begin{array}{l}69 \mathrm{~F} \\
76 \mathrm{M} \\
\end{array}$ & $\begin{array}{l}\text { Leg } \\
\text { Leg }\end{array}$ & $\begin{array}{l}\text { Growing mass ( } 20 \text { years) } \\
\text { Growing mass ( } 2 \text { months) }\end{array}$ & $\begin{array}{l}\text { Fibular fracture ( } 20 \text { years) } \\
\text { Tibia, fib fracture ( } 55 \text { years) }\end{array}$ & $\begin{array}{c}- \\
\text { Peroneal } \\
\end{array}$ & $\begin{array}{l}\text { Incisional } \\
\text { Incisional }\end{array}$ & $\begin{array}{l}\text { Yes } \\
\text { Yes }\end{array}$ & $\begin{array}{c}\text { Chronic drainage } \\
\text { Yes }\end{array}$ & $\begin{array}{c}- \\
\text { Debridement }\end{array}$ \\
\hline Güven et al. [27] & $66 \mathrm{M}$ & Leg & Mass, pain (12 months) & $\begin{array}{l}\text { Compartment syndrome } \\
\text { after gunshot injury of the } \\
\text { thigh ( } 35 \text { years) }\end{array}$ & - & Excisional & - & - & - \\
\hline
\end{tabular}

$\mathrm{M}=$ male; $\mathrm{F}=$ female; .. . $=$ not available VACT $=$ Vacuum Assisted Closure Therapy. 
A closed fracture or trauma often associated to compartment syndrome are the most common causes of calcific myonecrosis [1-3,5-17,19-27]; in two papers describing 14 cases, data on previous trauma were not available $[4,18]$. Trauma may consist of a fracture (26 cases), strain or ligamentous injury (10 cases), snake bite ( 2 cases) [16,23], and gunshot lesion ( 2 cases) $[25,27]$. A peroneal nerve injury was reported in nine cases $[5,6,14,17,24,25]$, and a sciatic nerve injury in two cases $[10,18]$. Clinical presentation usually includes a painful soft tissue mass; occasionally, as in the present patient, the mass can be painless, or present with signs of infection [7,17]. The mean interval from trauma to occurrence of clinical symptoms is 37.6 years (range, 5 years to 59 years); the mean duration of clinical symptoms is 3 months (range, 10 days to 20 years) $[17,24]$. The patient presented herein had a history of tibia and fibula fracture 40 years before; however, he experienced the growing palpable mass only after the second injury to the leg, as previously reported in one case [26].

Radiographs and CT scans usually show fusiform soft-tissue masses with longitudinal peripheral plaque-like calcifications resembling an eggshell, and multiple fragmented calcifications involving the entire compartment $[9,19]$. CT scans confirm the compartmental involvement and more clearly illustrate the peripheral calcification and periosteal erosions $[9,19]$. Bone erosion could be observed with smooth periosteal reaction [3]. Magnetic resonance (MR) imaging usually shows an iso- or hyperintense soft-tissue lesion with central liquefaction and hypointense coarse calcifications without enhancement after gadolinium administration [6]. Peripheral ring enhancement on postcontrast fat-suppression T1-weighted MR imaging has also been observed [14].

The differential diagnosis should include soft-tissue sarcomas with a propensity for calcifications (mineralization) or ossifications (dense bone formation) such as synovial sarcoma, epithelioid sarcoma and extraskeletal osteosarcoma, as well as benign lesions such as myositis ossificans and inflammatory diseases $[7,17,19]$. Synovial sarcoma, epithelioid sarcoma and extraskeletal osteosarcoma may radiographically resemble calcific myonecrosis; however, the calcific pattern in myonecrosis has a peripheral distribution with a central core of necrosis that is different from sarcomas in which calcifications/ossifications are usually distributed throughout the mass [17]. Myositis ossificans usually show calcifications with the absence of an intralesional trabecular pattern and marrow signal on MR imaging or progressive enlargement of the mass [7]. Other benign entities resembling calcific myonecrosis are post-traumatic pseudoaneurysms, dermatomyositis, polymyositis, diabetic myonecrosis and tumoral calcinosis; in these cases, respective systemic symptoms are quite evident $[2,10,26,28]$. Biopsy should be used in most cases that clinical and imaging appearance resemble a sarcoma for histological diagnosis. However, the surgeon (and patient) should be aware that biopsy potentially leads to more problems than it is worth. Regarding either a closed or an open biopsy, complications may occur, most commonly infection and wound healing problems [7]. Therefore, asymptomatic patients with a stable lesion, typical medical history (remote fracture, compartment syndrome) and imaging, should be watched rather than biopsied.

When calcific myonecrosis is confirmed, treatment is controversial. Various treatments have been reported; some authors have recommended surgical excision for symptomatic patients $[9,10]$, while others recommended aggressive debridement with flap coverage $[6,7,15]$, even if several have ultimately been unsuccessful or associated with complications $[4,6,7,18,23,24,26]$. Infection is the most common complication, accounting for approximately $62 \%$ of the reported cases after a surgical operation or even a biopsy procedure $[2-4,6,7,18,23,24,26]$. When it occurs, infection should be treated with wide spectrum antibiotics for $6-8$ weeks with a minimum of two weeks of intravenous administration $[2,7,15]$. Due to the high risk of infection, all authors agree that surgical intervention in asymptomatic patients should be avoided; conservative treatment with follow-up observation is the best option after documentation of the diagnosis. Malignant degeneration has not been reported. 


\section{Conclusions}

To conclude, calcific myonecrosis is a benign entity that usually affects the leg secondary to trauma. Biopsy is not necessary in asymptomatic patients with a stable lesion, typical medical history (remote fracture, compartment syndrome) and imaging. Conservative treatment with clinical and radiographic follow-up is the best treatment approach due to the high risk for infection.

Author Contributions: The following authors have designed the study: A.A., E.P., A.F.M., G.T., P.R.), performed specimen evaluation (R.C., G.N.F.), performed literature review: E.P., A.F.M., G.T., A.A., P.R., wrote the initial drafts: A.A., E.P., A.F.M., G.T., P.R.), and ensure the accuracy of the data and analysis: A.A., E.P., A.F.M., G.T., R.C., G.N.F., P.R.

Funding: This research received no external funding.

Conflicts of Interest: Each author certifies that he or she has no commercial associations (e.g., consultancies, stock ownership, equity interest, patent/licensing arrangements, etc.) that might pose a conflict of interest in connection with the submitted article.

\section{References}

1. Gallie, W.E.; Thomson, S. Volkmann's ischemic contracture: Two case reports with identical late sequelae. Can. J. Surg. 1960, 3, 164-166.

2. Wang, J.W.; Chen, W.J. Calcific myonecrosis of the leg. Clin. Orthop. Relat. Res. 2001, 389, 185-190. [CrossRef]

3. Larson, R.C.; Sierra, R.J.; Sundaram, M.; Inwards, C.; Scully, S.P. Calcific myonecrosis: A unique presentation in the upper extremity. Skelet. Radiol. 2004, 33, 306-309. [CrossRef]

4. Dhillon, M.; Davies, A.M.; Benham, J.; Evans, N.; Mangham, D.C.; Grimer, R.J. Calcific myonecrosis: A report of ten new cases with an emphasis on MR imaging. Eur. Radiol. 2004, 14, 1974-1979. [CrossRef]

5. Muramatsu, K.; Ihara, K.; Seki, T.; Imagama, T.; Taguchi, T. Calcific myonecrosis of the lower leg: Diagnosis and options of treatment. Arch. Orthop. Trauma. Surg. 2009, 129, 935-939. [CrossRef]

6. Janzen, D.L.; Connell, D.G.; Vaisler, B.J. Calcific myonecrosis of the calf manifesting as an enlarging soft-tissue mass: Imaging features. Am. J. Roentgenol. 1993, 160, 1072-1074. [CrossRef]

7. Holobinko, J.N.; Damron, T.A.; Scerpella, P.R.; Hojnowski, L. Calcific myonecrosis: Keys to early recognition. Skelet. Radiol. 2003, 32, 35-40. [CrossRef]

8. Batz, R.; Sofka, C.M.; Adler, R.S.; Mintz, D.N.; DiCarlo, E. Dermatomyositis and calcific myonecrosis in the leg: Ultrasound as an aid in management. Skelet. Radiol. 2006, 35, 113-116. [CrossRef]

9. O'Keefe, R.J.; O'Connell, J.X.; Temple, H.T.; Scully, S.P.; Kattapuram, S.V.; Springfield, D.S.; Rosenberg, A.E.; Mankin, H.J. Calcific myonecrosis. Clin. Orthop. Relat. Res. 1995, 318, $205-213$.

10. Zohman, G.L.; Pierce, J.; Chapman, M.W.; Greenspan, A.; Gandour-Edwards, R. Calcific myonecrosis mimicking an invasive soft-tissue neoplasm. A case report and review of the literature. J. Bone Joint Surg. Am. 1998, 80, 1193-1197. [CrossRef]

11. Flinn, J.; Beggs, I. Case of the month: Calcified leg. Br. J. Radiol. 1996, 69, 371-372. [CrossRef]

12. Ozbarlas, S.; Kalaci, A.; Ozkan, C.; Togrul, E. A previously healthy 77-year-old man with a painful mass in the calf for two months. Ann. Saudi. Med. 2007, 27, 49-50. [CrossRef]

13. De Carvalho, B.R. Calcific myonecrosis: A two-patient case series. Jpn. J. Radiol. 2012, 30, 517-521. [CrossRef]

14. Okada, A.; Hatori, M.; Hosaka, M.; Watanuki, M.; Itoi, E. Calcific myonecrosis and the role of imaging in the diagnosis: A case report. Ups. J. Med. Sci. 2009, 114, 178-183. [CrossRef]

15. Schneider, S.; Duewell, S.; Graf, H.; Forster, A. Painful swollen leg 52 years after bimalleolar fracture. Praxis 2009, 98, 1457-1461. [CrossRef]

16. Chun, Y.S.; Shim, H.S. Calcific myonecrosis of the antetibial area. Clin. Orthop. Surg. 2010, 2, $191-194$. [CrossRef]

17. Papanikolaou, A.; Chini, M.; Pavlakis, D.; Lioni, A.; Lazanas, M.; Maris, J. Calcific myonecrosis of the leg: Report of three patients presenting with infection. Surg. Infect. 2011, 12, 247-250. [CrossRef]

18. Portabella, F.; Nárvaez, J.A.; Llatjos, R.; Cabo, J.; Maireles, M.; Serrano, C.; Pedrero, S.; Romero, E.; Pablos, O.; Saborido, A. calcific myonecrosis of the leg. Rev. Esp. Cir. Ortop. Traumatol. 2012, 56, 46-50. [CrossRef]

19. O’Dwyer, H.M.; Al-Nakshabandi, N.A.; Al-Muzahmi, K.; Ryan, A.; O'Connell, J.X.; Munk, P.L. Calcific myonecrosis: Keys to recognition and management. Am. J. Roentgenol. 2006, 187, W67-W76. [CrossRef] 
20. Jalil, R.; Roach, J.; Smith, A.; Mukundan, C. Calcific myonecrosis: A case report and review of the literature. BMJ Case Rep. 2012, 2012, bcr2012007186. [CrossRef]

21. Karkhanis, S.R.; Botchu, R.; James, S.; Evans, N. Bilateral calcific myonecrosis associated with epilepsy. Clin. Radiol. 2013, 68, 349-352. [CrossRef] [PubMed]

22. Rynders, S.D.; Boachie-Adjei, Y.D.; Gaskin, C.M.; Chhabra, A.B. Calcific myonecrosis of the upper extremity: Case report. J. Hand. Surg. Am. 2012, 37, 130-133. [CrossRef] [PubMed]

23. Yuenyongviwat, V.; Laohawiriyakamol, T.; Suwanno, P.; Kanjanapradit, K.; Tanutit, P. Calcific myonecrosis following snake bite: A case report and review of the literature. J. Med. Case Rep. 2014, 8, 193. [CrossRef] [PubMed]

24. Ukon, Y.; Tanaka, T.; Nagata, S.; Hagizawa, H.; Imura, Y.; Tamiya, H.; Oshima, K.; Naka, N.; Aoki, Y.; Kuratsu, S. Calcific myonecrosis mimicking soft tissue sarcoma: A case report. Oncol. Lett. 2018, 15, 7909-7913. [CrossRef] [PubMed]

25. Tuncay, I.C.; Demirörs, H.; Isiklar, Z.U.; Agildere, M.; Demirhan, B.; Tandogan, R.N. Calcific myonecrosis. Int. Orthop. 1999, 23, 68-70. [CrossRef] [PubMed]

26. Jassal, D.S.; Low, M.; Ross, L.L.; Zeismann, M.; Embil, J.M. Calcific myonecrosis: Case report and review. Ann. Plast. Surg. 2001, 46, 174-177. [CrossRef] [PubMed]

27. Güven, M.; Cakar, M.; Başsorgun, I.; Kadioğlu, B.; Kilinçoğlu, V.; Eren, A. Calcific myonecrosis. Acta. Orthop. Traumatol. Turc. 2008, 42, 70-73. [CrossRef] [PubMed]

28. Mirra, J.M. Calcific myonecrosis. Clin. Orthop. Relat. Res. 1996, 327, 308-310. [CrossRef]

(C) 2019 by the authors. Licensee MDPI, Basel, Switzerland. This article is an open access article distributed under the terms and conditions of the Creative Commons Attribution (CC BY) license (http://creativecommons.org/licenses/by/4.0/). 